\title{
Length-weight relationship and relative condition factor of the Stone Scorpionfish Scorpaena mystes in the central area of the Gulf of California, Mexico
}

\author{
Relación longitud-peso y factor de condición relativo del pez escorpión roquero Scorpaena mystes en la parte central del Golfo de \\ California, México
}

Ulianov Jakes-Cota ${ }^{1}$, Arturo Tripp-Valdez ${ }^{1}$ and Francisco 0. López-Fuerte ${ }^{2}$

1Instituto Politécnico Nacional, Centro Interdisciplinario de Ciencias Marinas. Departamento de Pesquerías y Biología Marina. A.P. 592. La Paz, Baja California Sur, 23096. México

${ }^{2}$ Universidad Autónoma de Baja California Sur. Departamento Académico de Economía, Laboratorio de Sistemas Arrecifales. Carretera al Sur, km. 5.5., A.P. 19-B, La Paz, Baja California Sur, 23080. México email: atrippv@ipn.mx

Recibido: 17 de junio de 2016.

Aceptado: 7 de diciembre de 2016

Jakes-Cota U., A. Tripp-Valdez, and F. 0. López-Fuerte. 2017. Length-weight relationship and relative condition factor of the Stone Scorpionfish Scorpaena mystes in the central area of the Gulf of California, México. Hidrobiológica 27(1): 127-129. D0l: 10.24275/uam/izt/dcbs/hidro/2017v27n1/Tripp

\section{ABSTRACT}

Background. In recent years (since 2012) there has been an increase in the commercial exploitation of Scorpaena mystes Jordan \& Starks, 1985 in the central area of the Gulf of California and there is no information on the basic biology of this species that serve as a basis to determine the current population status and, in the future, assess any changes associated with exploitation and environmental factors. Goals. Determine the length-weight (LWR) and length-length (LLR) relationships, and the relative condition factor of $S$. mystes. Methods. Fish specimens $(n=258)$ were collected monthly from May 2015 through April 2016 in waters off Santa Rosalía, Baja California Sur. Each fish was measured for standard length (SL) and total length (TL), and weighed (W). Results. LWR and LLR were highly significant $(p<0.05)$ with a determination coefficient higher than 0.9 . The $b$-value $(b=3.06)$ of LWR was not significantly-different from 3 . Monthly variation in the relative condition factor was also significant $(p<0.05)$ with the highest value in August (1.34). Conclusions. The growth of $S$. mystes is isometric. The monthly variation in the condition factor may be associated with maturation of the gonads of the species.

Key words: Condition factor, isometric growth, LLR, LWR, Scorpaena mystes.

\section{RESUMEN}

Antecedentes. En años recientes (desde 2012) ha existido un aumento en la explotación comercial de Scorpaena mystes Jordan \& Starks, 1895 en la parte central del Golfo California y no existe información sobre su biología básica que sirva de base para determinar el estado actual de la población y, en el futuro, evaluar cualquier cambio asociado con la explotación del recurso y factores ambientales. Objetivos. Determinar las relaciones longitud-peso (LWR) y longitud-longitud (LLR), así como el factor de condición relativo de $S$. mystes. Métodos. Los peces $(n=258)$ fueron capturados mensualmente de mayo de 2015 a abril de 2016 en aguas costeras de Santa Rosalía, Baja California Sur. De cada pez se registraron la longitud estándar (LE) y total (LT), y el peso (P). Resultados. Las LWR y LLR fueron altamente significativas $(p<0.05)$ con un coeficiente de determinación mayor a 0.9 . El valor de $b(b=3.06)$ de la LWR no fue significativamente diferente de 3. La variación mensual del factor de condición relativo también fue significativa $(p<0.05)$, con el valor más alto en agosto (1.34). Conclusiones. El crecimiento de $S$. mystes es isométrico. La variación mensual del factor de condición puede estar asociada a la maduración de las gónadas de la especie.

Palabras clave: Crecimiento isométrico, factor de condición, LLR, LWR, Scorpaena mystes.

The Stone Scorpionfish, Scorpaena mystes Jordan \& Starks, 1895, is a shallow-water species that occurs commonly on seaweed-covered reefs and in open, sandy areas. It is the most abundant species of the Scorpaenidae family along the eastern coast of the Baja California Peninsula, and ranges widely from southern California to Chile, including Isla Guadalupe, Gulf of California, Galápagos Islands, and other offshore islands (Thomson et al., 2000; Butler et al., 2012). Although the flesh is of excellent quality, Stone Scorpionfish is only a minor species for artisanal fisheries in the Gulf of California due to the venomous spines, 
which can cause painful wounds and respiratory disorders (Poss, 1995). However, the central portion of the east coast of the Baja California peninsula, particularly the area around Santa Rosalía, Baja California Sur, has witnessed an increase in its commercialization in recent years (since 2012), as it has moved quickly from being considered a third-class, low-priced fish to gaining a reputation as a top-quality product that has increased in both price and capture volume (López-Fuerte, Comm. pers.). For these reasons, and because there is no information on the basic biology of this species, it is important to conduct studies such as this one, that serve as a basis to determine the current population status and, in the future, assess any changes associated with exploitation (artisanal fisheries) and environmental factors.

Evaluating the population size of a commercially-important fish species for its rational exploitation requires knowledge of the individual body length-weight relationship (LWR) (Dulčić et al., 1994) because this provides important information on the condition of the fish and determines whether somatic growth is isometric or allometric. This is also very useful for determining the mean weight for a group of a given length, converting length observations into weights to provide a measure of biomass, and permitting the conversion of growth-in-length to growth-in-weight equations (Froese, 2006; Le Cren, 1951; Ricker, 1975). Hence, the aim of this study was to determine the LWR and relative condition factor of $S$. mystes from the central area of the west coast of the Gulf of California.

Fish specimens were collected monthly from May 2015 through April 2016 in waters off Santa Rosalía, Baja California Sur (27'19'45.14" $\mathrm{N}, 112^{\circ} 15^{\prime} 13.40^{\prime \prime} \mathrm{W}$ ). Fish were caught manually with handheld spears using semi-autonomous diving equipment (hookah) in waters up to 30 $\mathrm{m}$ depth. Each fish was measured for standard length (SL) and total length (TL) to the nearest $0.1 \mathrm{~cm}$, and weighed $(W)$ to the nearest $0.1 \mathrm{~g}$.

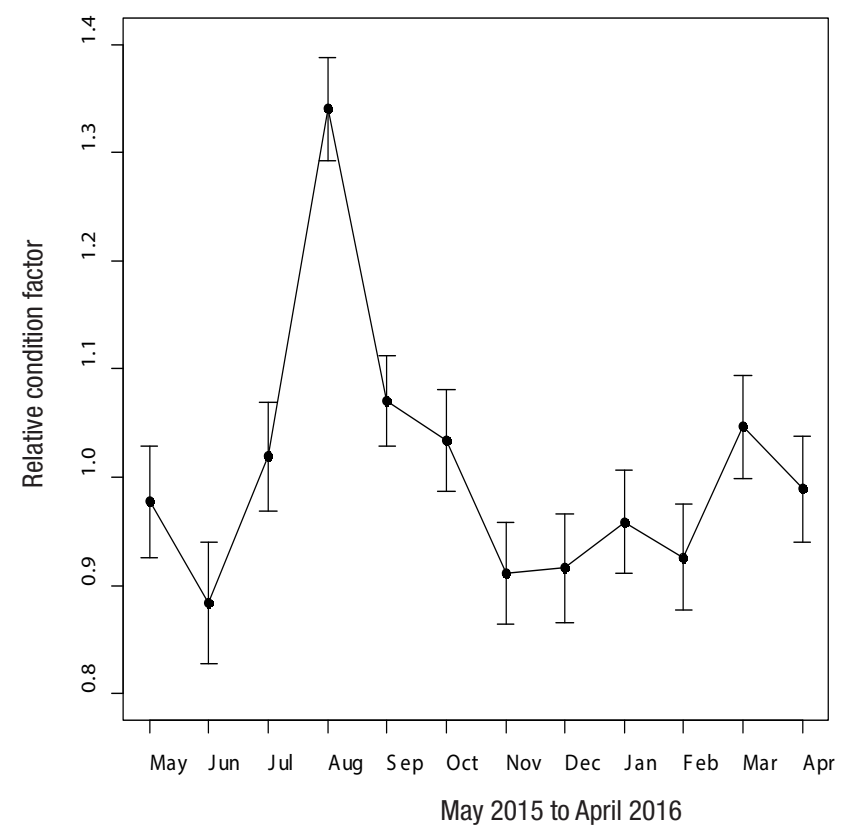

Figure 1. Monthly variation in the relative condition factor $(K n)$ of Scorpaena mystes from the central area of the Gulf of California, Mexico. Vertical lines indicate $95 \%$ confidence intervals of $K n$.
LWR was described using the allometric equation: $W=a T L^{b}$, where $W$ is the weight $(\mathrm{g}), \mathrm{TL}$ is total length $(\mathrm{cm})$, and $a$ and $b$ represent the intercept and slope of the regression line, respectively (Froese, 2006), which were estimated using a simple linear regression analysis of logtransformed data $(\log W=\log a+b \log \mathrm{TL})$. In order to evaluate whether the $b$-value was significantly different from isometric growth $(b=$ 3 ), a Student's $t$-test was performed (Zar, 2010). In addition, the SL vs. TL relationship (LLR) was determined by simple linear regression (TL $=a+b \mathrm{SL})$. Finally, the relative condition factor $(K n)$ for each month was calculated by the equation $K n=W \cdot W \mathrm{e}^{-1}$, where $W$ is the observed weight of the fish and We is the predicted weight derived from the LWR (Le Cren, 1951). One-way analysis of variance was used to assess differences in mean monthly $\mathrm{Kn}$. All statistical analyses were performed using $\mathrm{R}$ programming language (R Core Team, 2016).

A total of 258 Stone Scorpionfish were measured and weighed during the sampling period (21-22 per month). TL ranged from 15.3-44.5 $\mathrm{cm}$, with a mean of $26.76 \mathrm{~cm}$, while SL varied from $12.5-36.5 \mathrm{~cm}$, with a mean of $21.57 \mathrm{~cm}$. The weight range was $64-1,870 \mathrm{~g}$, with a mean of $470.59 \mathrm{~g}$. The LLR was highly significant $(p<0.001)$ with a high determination coefficient $\left(r^{2}=0.98\right)$, and was expressed by the following equation: $\mathrm{TL}=2.249+1.136 \mathrm{SL}$.

The LWR was also highly significant $(p<0.001)$ with a high determination coefficient $\left(r^{2}=0.92\right)$, and was expressed by the equation $\log W=\log -1.75+3.06 \log \mathrm{TL}$, with a $95 \%$ confidence interval for $b$ from 2.95 to 3.17. The estimated $b$-value of the LWR of $S$. mystes was within the expected range of values reported for fishes $(b=2.5-3.5)$ (Froese, 2006), and $b$-values outside this range are generally considered erroneous (Ricker, 1975). In addition, the results of the Student's $t$-test showed that the $b$-value was not significantly different than 3 , proving that the growth of $S$. mystes is isometric (i.e. growth of all body parts is consistent and proportional throughout development) (Bagenal \& Tesch, 1978).

Variation in the relative condition factor between months was significant $\left(F_{(11,246)}=23.95, p<0.001\right)$. One significant peak (Tukey test, $p<$ 0.05 ) was observed in August 2015, followed by a steady decline until November 2015 (Fig. 1). The second-highest value, not significantly different (Tukey test, $p>0.05$ ) from other months, was recorded in March 2016 , while the lowest value was recorded in June 2015. High values for the condition factor are usually due to a high rate of feeding or gonadal maturation, while low values may be associated with limited food availability and weight loss after spawning (Froese, 2006; Le Cren, 1951). In order to better understand the variation observed in the condition factor of this species, additional studies on feeding habits and reproduction, as well as additional analyses by sex, are needed.

Before this study, no LWR and LLR parameters were available for S. mystes (Froese \& Pauly, 2016). Further studies need to be conducted, as no information exists on the impact of artisanal fishing on Stone Scorpionfish populations, or on basic aspects of the biology of this species.

\section{ACKNOWLEDGEMENTS}

FOLF currently holds a postdoctoral research grant from CONACYT. ATV thanks EDI from the Instituto Politécnico Nacional. 


\section{REFERENCES}

BAgenAL, T.B. \& F.W. TESCH. 1978. Age and growth In: Bagenal, T.B. (Ed.) Methods for assessment of fish production in freshwater. Blackwell Scientific Publications, 0xford, England, pp. 101-136.

ButLer, J. L, M. S. Love \& T.E. LaIDIG. 2012. A guide to the rockfishes, thornyheads, and scorpionfishes of the Northeast Pacific. University of California Press, California, USA. 185 p.

Dulčić, J., M. KRALJević \& P. CetinIć. 1994. Length-weight relationship in damselfish (Chromis chromis L. 1758) from the Eastern Adriatic during spawning. Acta Ichthyologica et Piscatoria 2 (24): 147-154. DOI: 10.3750/AIP1994.24.2.14

Froese, R. 2006. Cube law, condition factor and weight-length relationships: history, meta-analysis and recommendations. Journal of Applied Ichthyology 22 (4): 241-253. DOI: 10.1111/j.14390426.2006.00805.x

Froese, R. \& Pauly D. (Eds.) 2016. FishBase. World Wide Web electronic publication. www.fishbase.org, versión (01/2016).
LE CREn, E. D. 1951. The length-weight relationship and seasonal cycle in gonad weight and condition in the perch (Perca fluviatilis). Journal of Animal Ecology 20 (2): 201-219. D0I: 10.2307/1540

Poss, S. G. 1995. Scorpaenidae. In: Fischer, W., F. Krupp, W. Schneider, C. Sommer, K.E. Carpenter \& V.H. Niem (Eds.) Guía FAO para la identificación de especies para los fines de la pesca. Pacífico Centro-Oriental. Volumen III. Vertebrados Parte 2. FA0, Rome, Italy. pp. 1544-1564

R Core Team. 2016. R: A language and environment for statistical computing. R foundation for statistical computing, Vienna, Austria. https:// www.R-project.org/.

RICKER, W. E. 1975. Computation and interpretation of biological statistics of fish population. Department of the Environment Fisheries and Marine Service, Ottawa, Canada.

Thomson, D.A., L.T. Findley \& A.N. KeRSTitch. 2000. Reef fishes of the Sea of Cortez: The rocky-shore fishes of the Gulf of California. University of Texas Press, Austin, USA. 407 p.

ZAR, J. H. 2010. Biostatistical Analysis. Prentice Hall, Upper Saddle River, New Jersey, USA. 944 p. 